
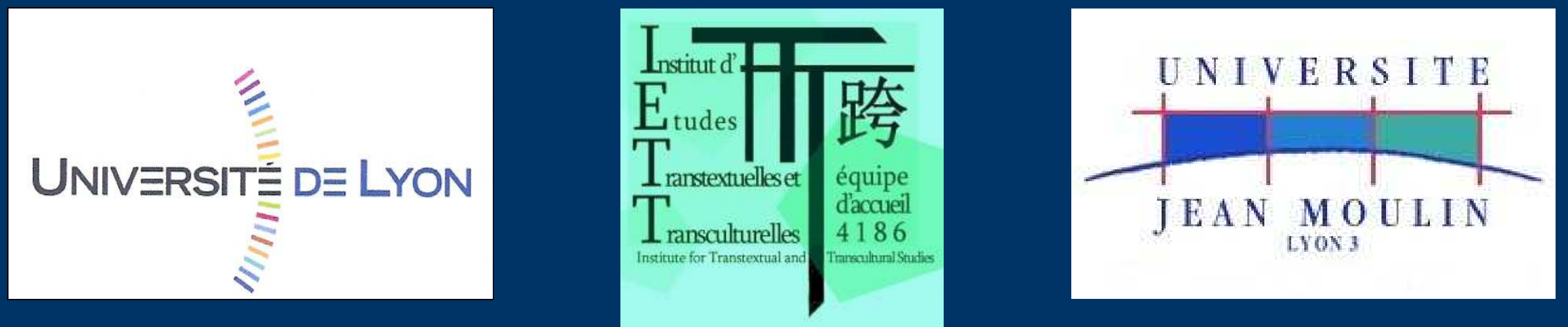

\title{
Taking Asia for an Object: The Big Mis(s-)take
}

\section{Gregory Lee}

Institute for Transtextual and Transcultural Studies

University of Lyons (Jean Moulin)

www.gregorylee.net; www.iett.eu 


\section{5* TABVLA A IAE VIII.}

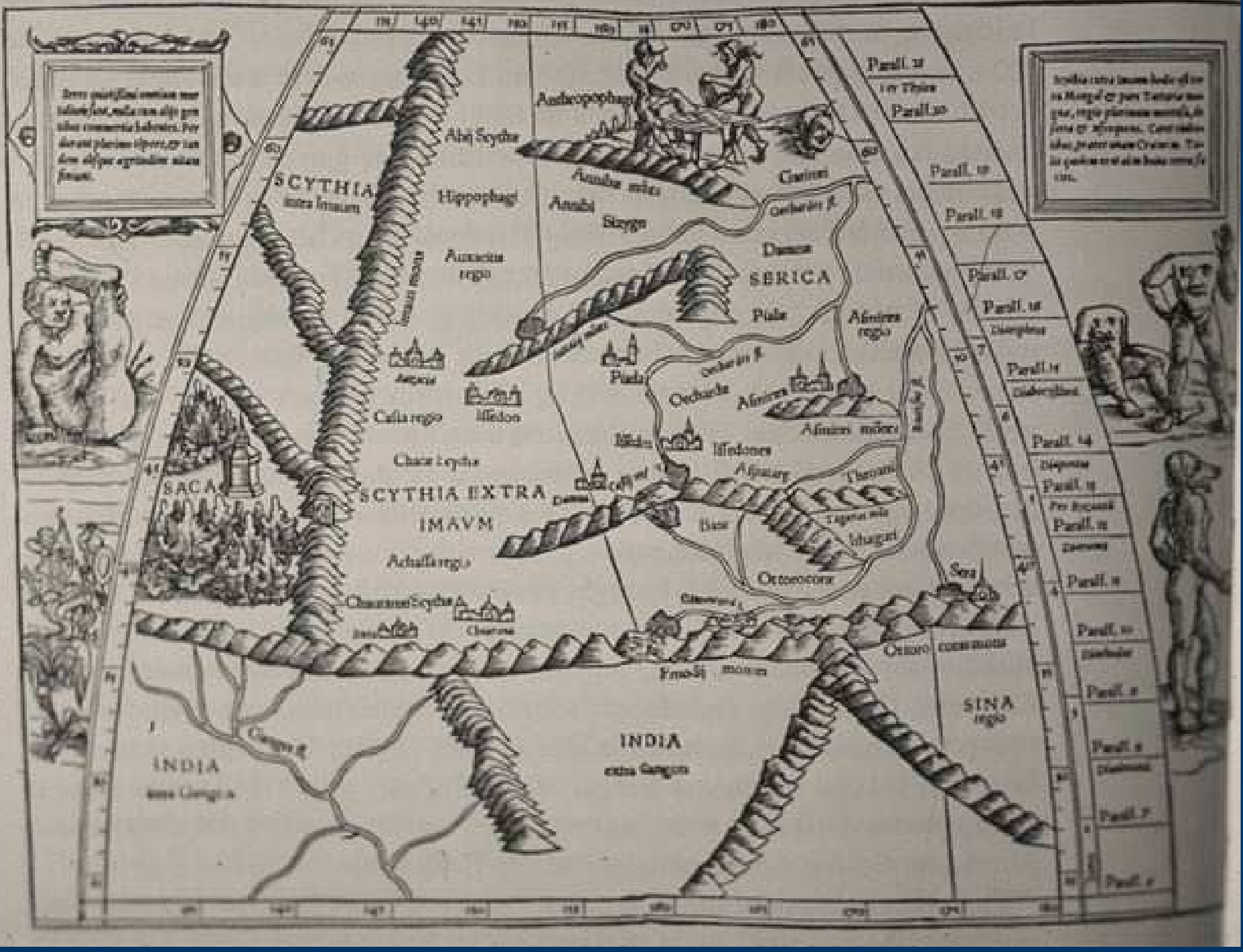




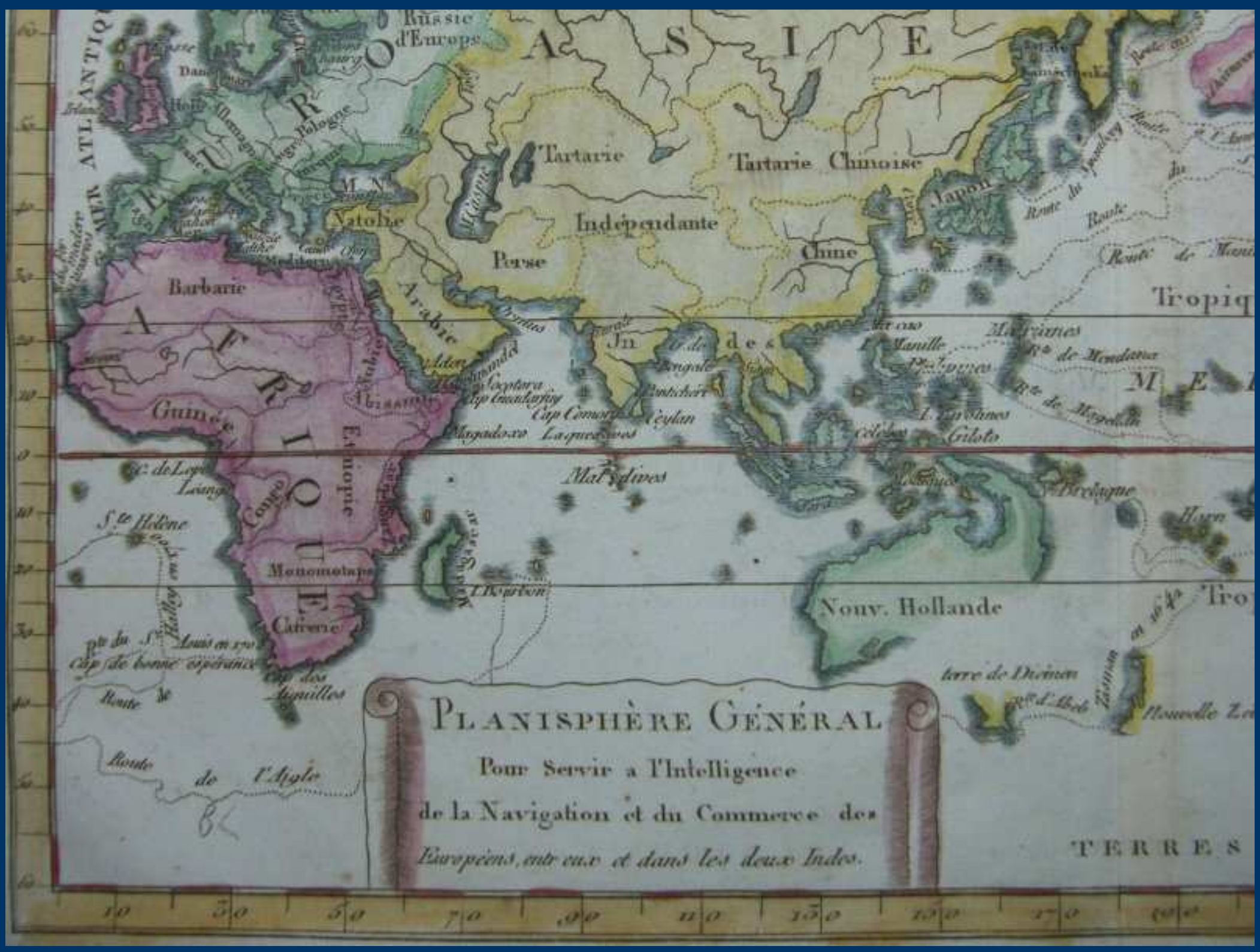




\section{CHILDREN'S CRUSADE AGAINST COMMUNISM}

47.

\section{War-Maker}

Mao Tse-tung is the leader of the Chinese Reds who attacked the United Nations forces in Korea. His army was built up, in the first place, with the help of outlaws. Later the Russian Reds supplied him with arms and advisers. He captured the China mainland in three years of savage warfare against the Nationalist government. Mao delights in war. History, he says, "is written in blood and iron." The free world must find a way to keep war-makers like Mao Tse-tung from shedding the blood of innocent people.
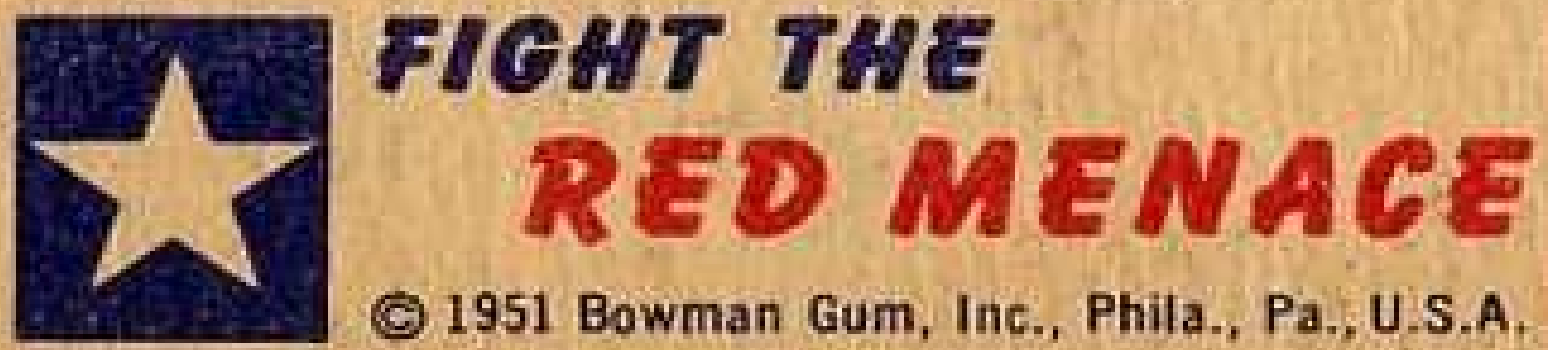

C 1951 Bowman Gum, Inc., Phila., Pa, U.S.A.

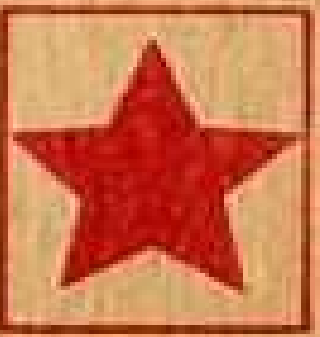




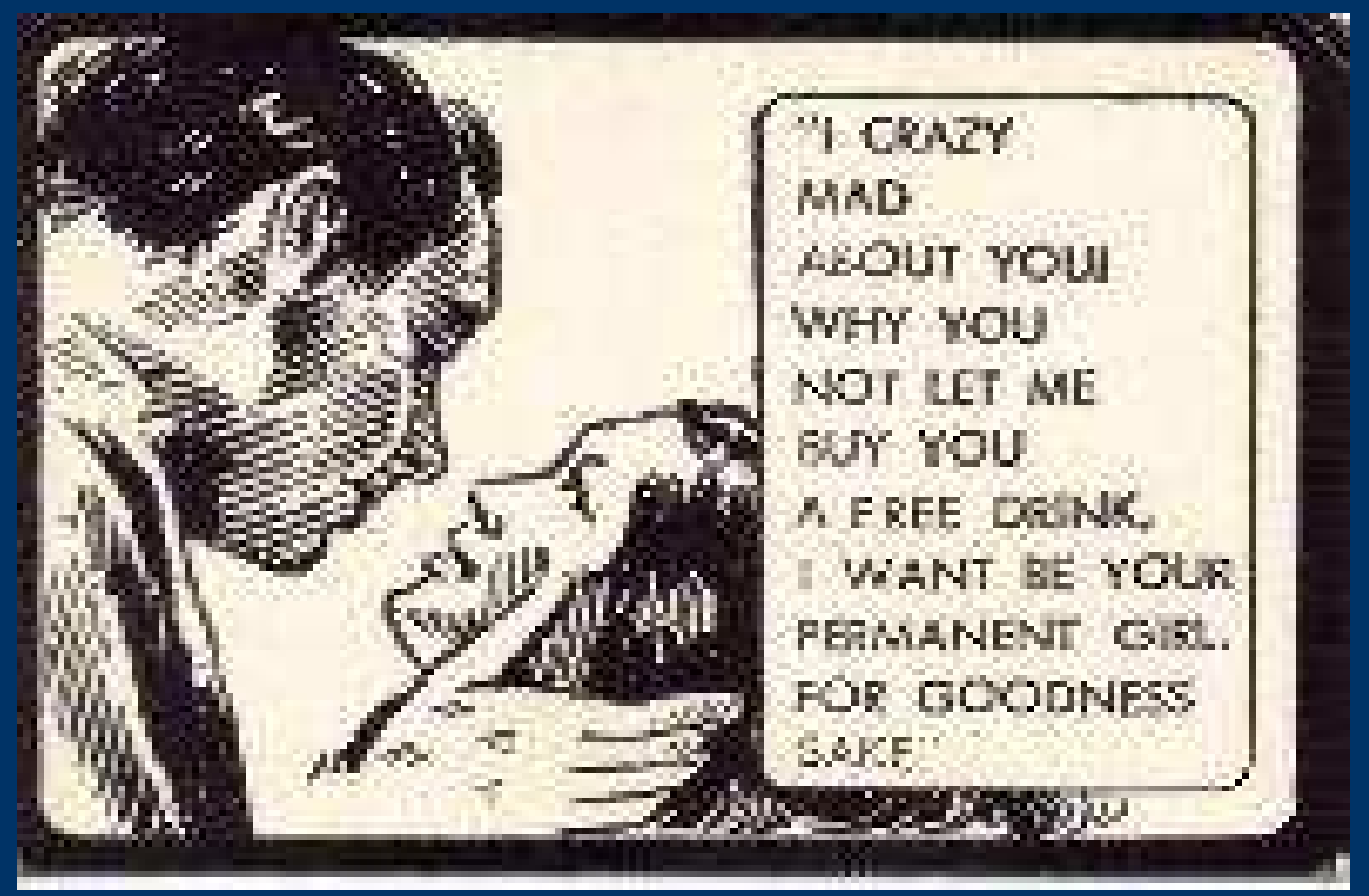

Suzy Wong invented by Richard Mason, 1957 


\section{The original Yellow Peril drawing based on Kaiser Wilhelm II's allegorical sketch.}

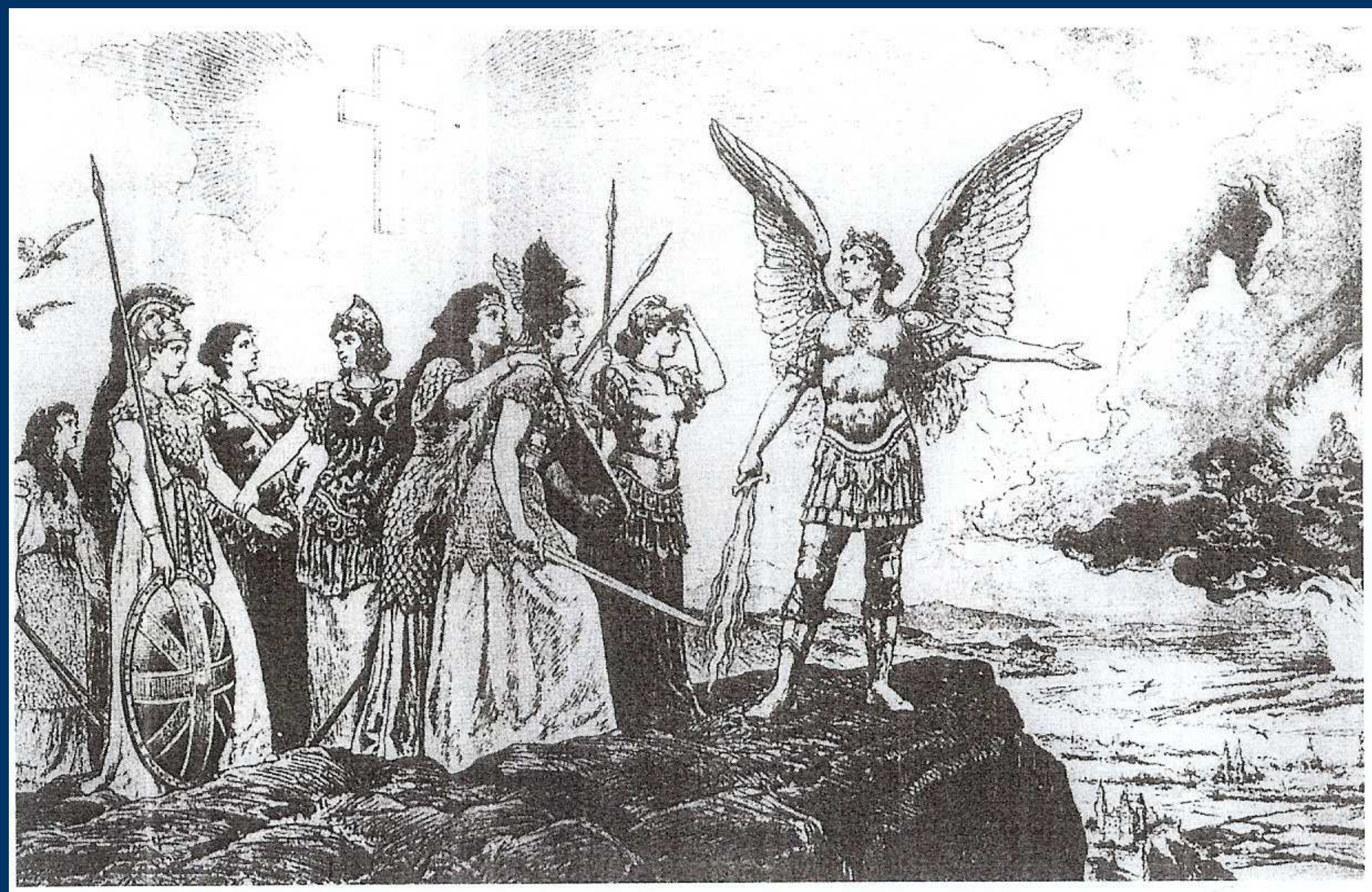

"Le Péril jaune". Dessin inspiré par une esquisse de Guillaume II, exemplaire dédicacé et signé par l'empereur: L'archange saint Michel invite les nations chrétiennes à s'unir contre l'orage chinois que domine assez curieusement le Bouddha.

Extrait de Jacques Brosse, La Découverte de la Chine, Paris, Bordas, 1981, p. 90. (Bibliothèque des arts décoratifs, Paris.) 


\section{Yokomitsu Riichi}

横光利

(1898-1947)

SHANGHAI
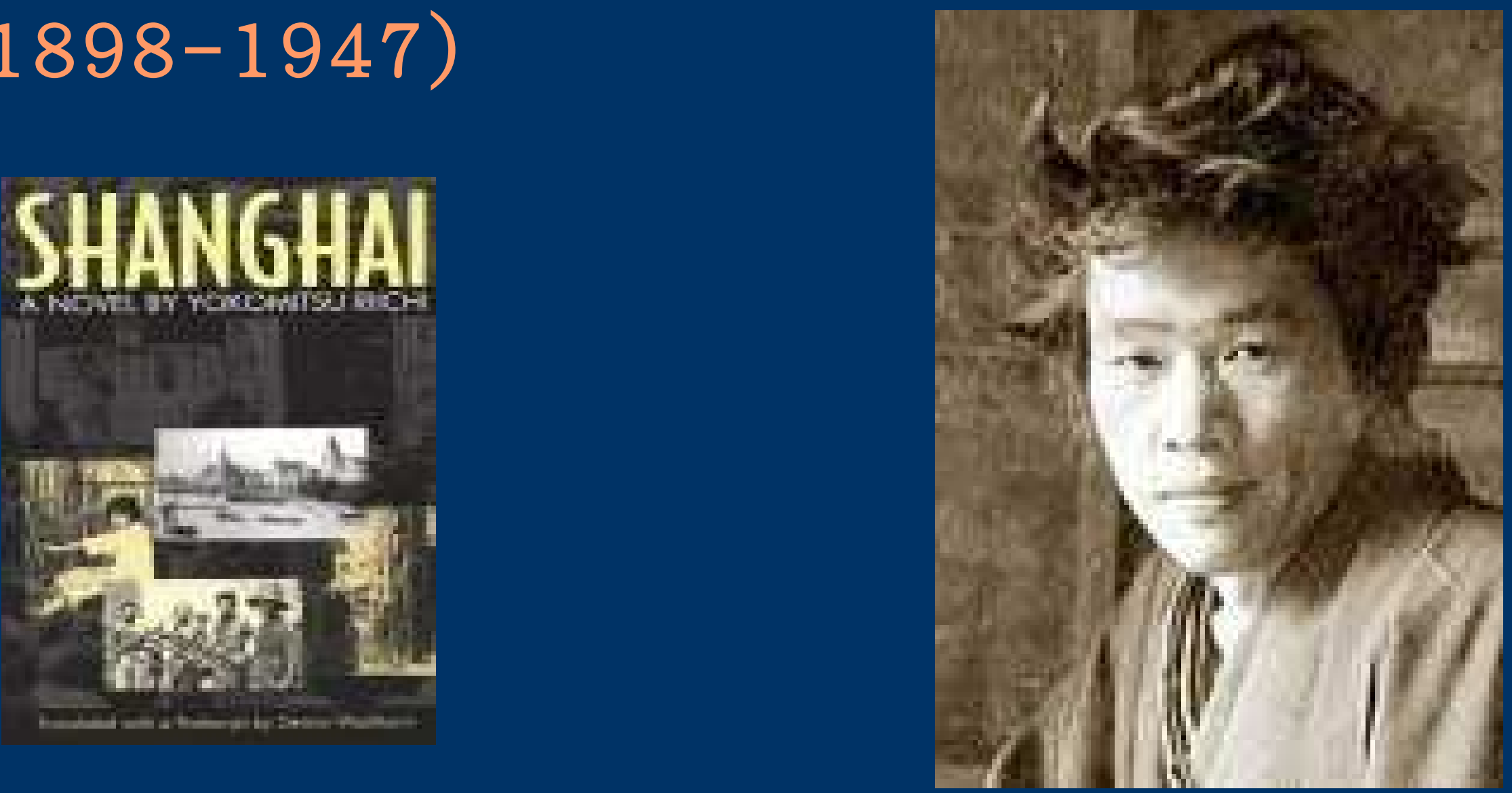


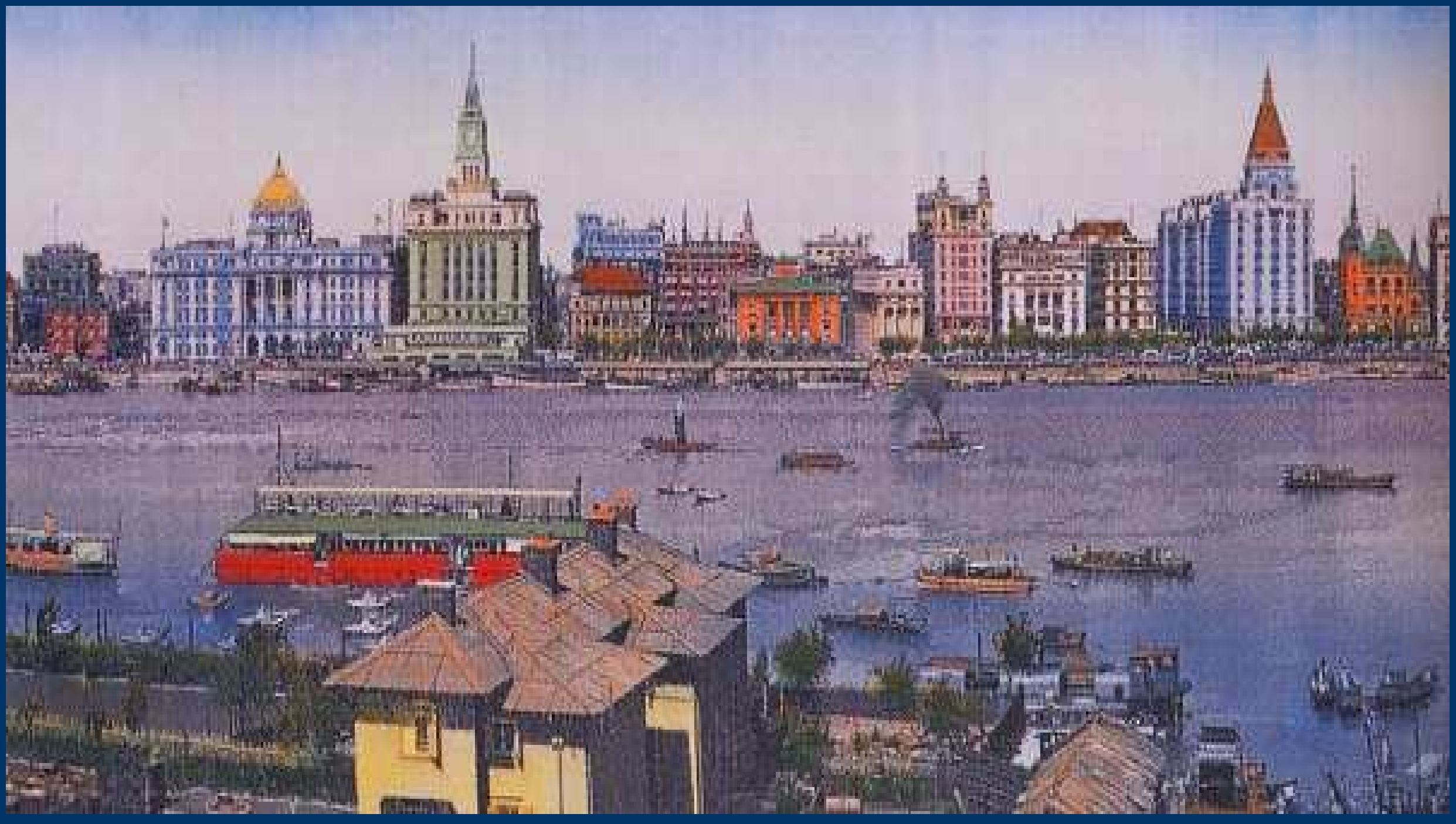




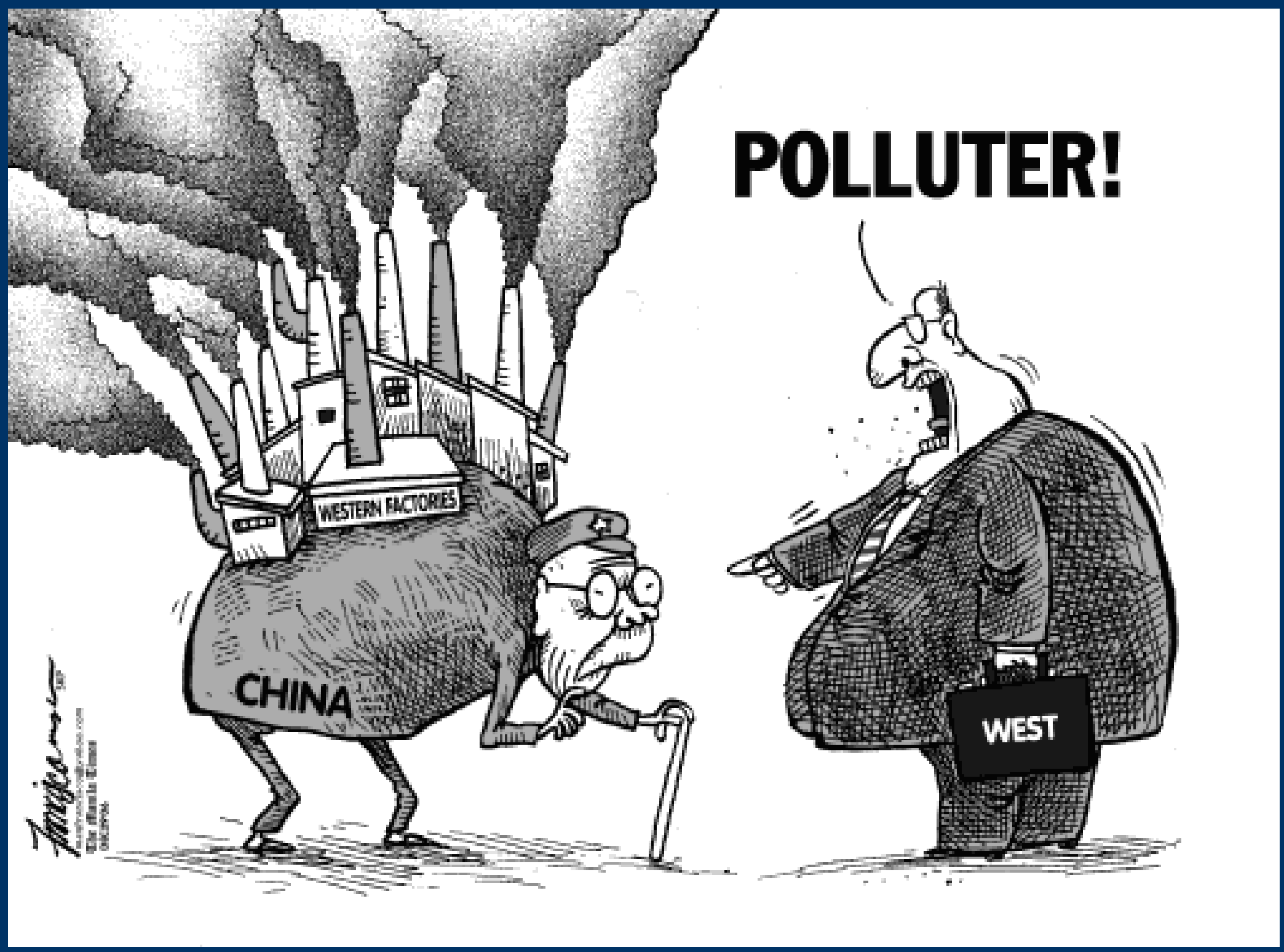

\section{'the polluter is China', Manny Francisco}



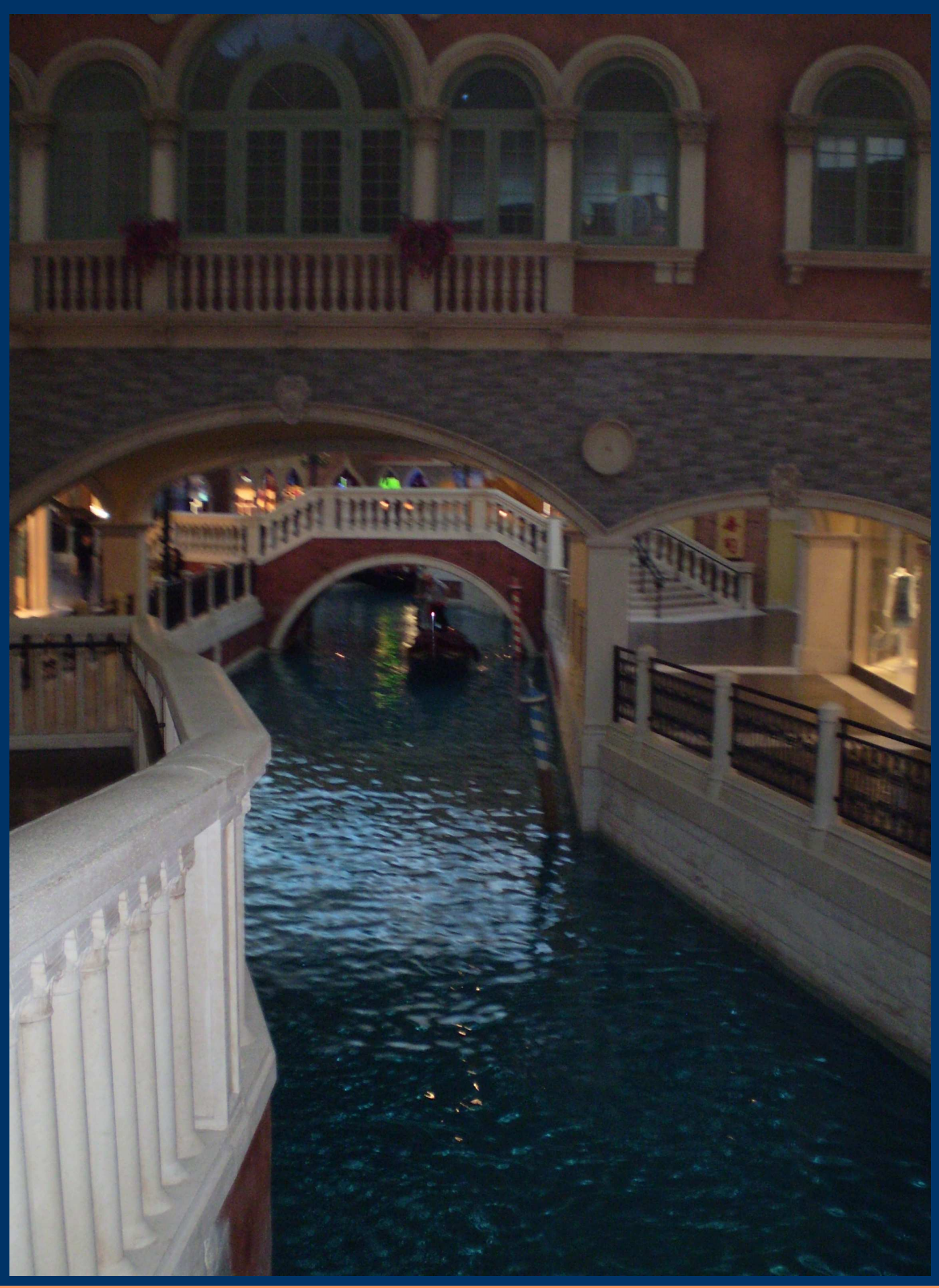


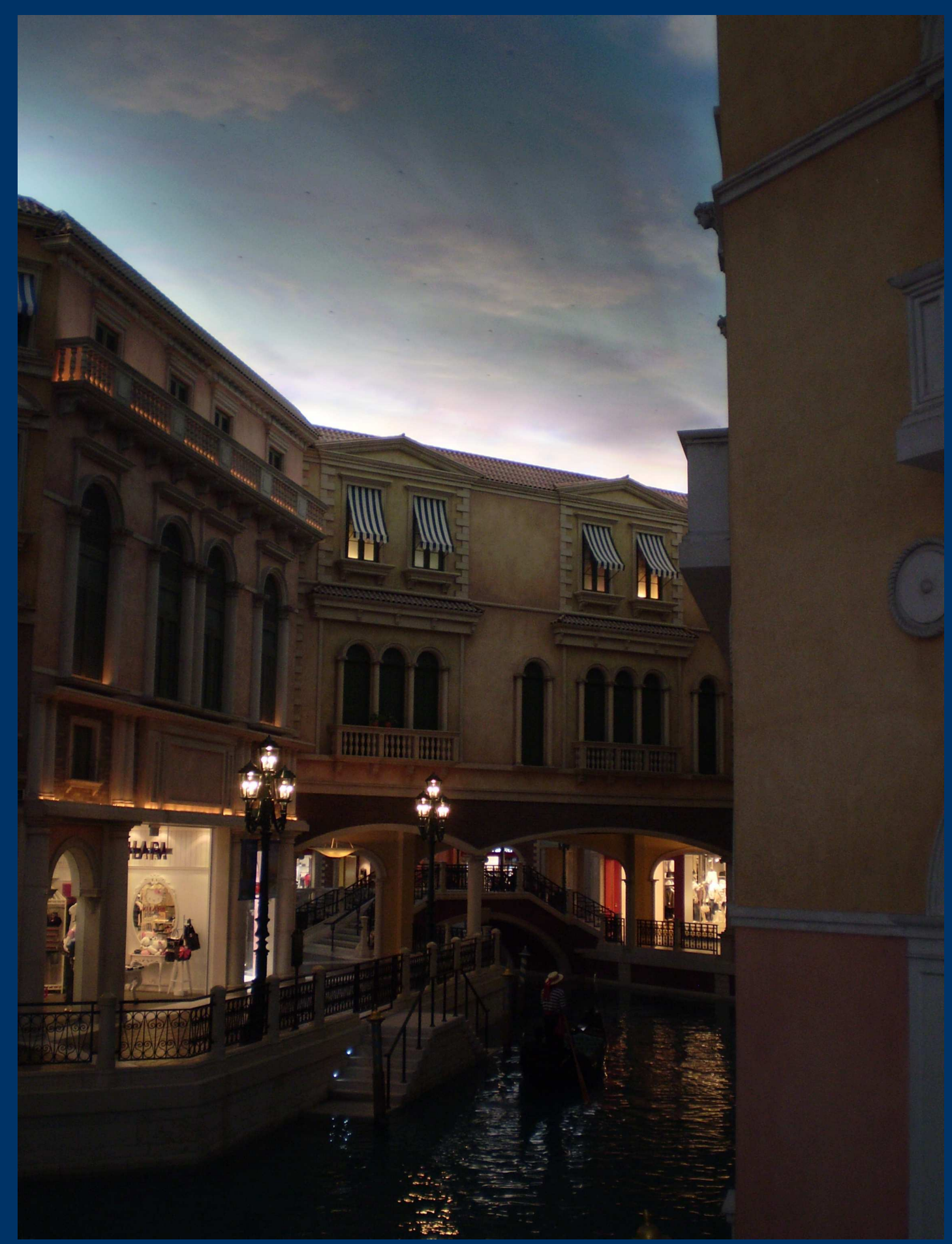



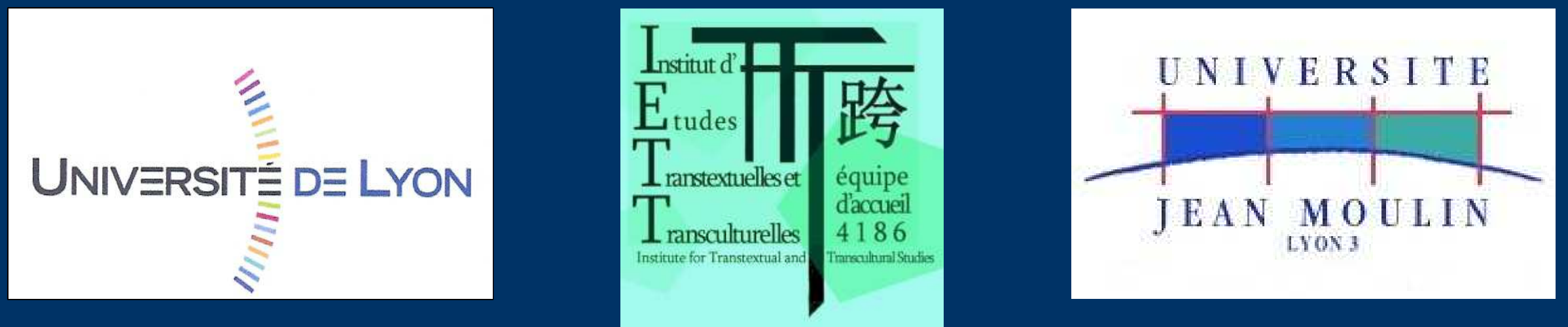

\section{Taking Asia for an Object: The Big Mis(s-)take}

\section{Gregory Lee}

Institute for Transtextual and Transcultural Studies

University of Lyons (Jean Moulin)

www.gregorylee.net; www.iett.eu 